\title{
AGRO-ECONOMIC DEVELOPMENT BASED ON THE ECONOMY OF KNOWLEDGE, BUSINESS AND SOCIAL SKILLS
}

Marija Cukanovic-Karavidic ${ }^{1}$, Slavko Karavidic ${ }^{2}$,Radovan Pejanovic ${ }^{3}$

*Corresponding authorE-mail: cukanovickaravidicmarija@gmail.com

\begin{tabular}{|c|c|}
\hline A R T I C L E I N F O & A B S T R A C T \\
\hline Review Article & \multirow{9}{*}{$\begin{array}{l}\text { In this paper, we tried to point out the contemporary } \\
\text { global trends of agrarian development that generate new } \\
\text { knowledge, a new way of learning, new innovative and } \\
\text { creative techniques of professional training - business } \\
\text { and social skills. Intention is to provide support and } \\
\text { encouragement to enter new forms of agrarian business. } \\
\text { Since education, as a dominant need for agrarian research, } \\
\text { is in the function of labor or occupation, we wanted to } \\
\text { provide an insight into the educational needs required for } \\
\text { professional education and training, as well as how much } \\
\text { the content of work in the agrarian defines educational } \\
\text { needs and expresses interest in vocational education and } \\
\text { training, by affirming practice through the realm of work } \\
\text { and business results. }\end{array}$} \\
\hline Received: 18 June 2018 & \\
\hline Accepted: 05 September 2018 & \\
\hline doi:10.5937/ekoPolj1803241C & \\
\hline UDC $338.435: 631.1$ & \\
\hline Keywords: & \\
\hline agriculture, agrarian, & \\
\hline $\begin{array}{l}\text { knowledge, innovation, success, } \\
\text { weather }\end{array}$ & \\
\hline JEL: I25, O15, O31, O35, I29 & \\
\hline
\end{tabular}

(C) 2018 EA. All rights reserved.

\section{Introduction}

Long-standing economic and transition crisis and social problems expressed by structural imbalance and poverty serve to fuel fresh thoughts and knowledge having the scientific importance in terms of responsible and active adaptation of agrarian changes processes based on global knowledge and skills.

Contemporary global agrarian trends generate new knowledge that requires new ways of learning, modern success formula and new innovative and creative techniques. Knowledge is the main driver of change and those values. Winners are those who are able to bring in the necessary changes, bring ideas, energy, the passion of creation, innovators, entrepreneurial drive, and all this requires knowledge and a positive attitude towards the work

1 Marija Cukanovic-Karavidic PhD, Associate Proffesor, Faculty of Business Economics and Enterpreneurship in Belgrade, Bulevar Kralja Aleksandra 334-11, 11000 Belgrade, Serbia, Phone: +38160722 00 11, E-mail: cukanovickaravidicmarija@gmail.com

2 Slavko Karavidic PhD, Full Professor, Faculty of Business Economics and Enterpreneurship in Belgrade, Vojvode Blažete 6a, 11000 Beograd, Serbia, Phone: + 3816020221 15, E-mail: skaravidic@gmail.com

3 Radovan Pejanović PhD, Full Professor, Faculty of Agriculture, University in Novi Sad, E-mail: pejanovic@uns.ac.rs

http://ea.bg.ac.rs 
The forementioned implies a correct attitude towards education, reflected in the influence on establishing a positive attitude and the impact on the deepening of interest in knowledge based on one's own determination and needs.

"The Global passport" is provided only to educated innovative staff thinking differently, crush the old concepts and offer new innovative ideas.

As Dositej Obradovic, a great philosopher and educator once said, "We need a school of knowing life and people, an active school of a reasonable man, work and learning, which provides the necessary experience". Nothing has changed until now.

Success is a group of values shown. To succeed, it is important to have a choice, let the future happen. Great goals are seen only by big players

Great success is a triumph of perseverance and knowledge (Sigmund Freud)

\section{The success formula - knowledge and skills equals success in agriculture}

Agriculture as the pillar of the economic development of the Republic of Serbia has an invaluable social significance (multiplier effect on overall economic growth and development) and impact on social stability.

Increased transitional contradictions in agriculture and interest matrix are a consequence of the agrarian system and structural crisis are found at a complex crossroads and numerous problems of agrarian development. No fundamental relationship was present to the content and forms of transition in which agrarization with the development of entrepreneurship should have been the key to Serbian economic growth and development.

For the agrarian development, creative power of knowledge and intellectual potential is vital - education as a process of acquiring knowledge, building skills, adopting a system of values, new technologies, business and organizational culture.

The economy of knowledge is the main tool in creating a new model of economic and social growth and development. (Pejanovic, 2013, p. 613) Modern agrarian development requires changes of institutional basis, creative modernization in terms of production, technology, changes in the labor organization and management and strong development of production forces and their applicative ability, as well as appropriate incentives.

Knowledge, production and innovations are the most important sources of change and represent the basis for the construction of a modern agrarian system based on business knowledge and social skills. EU Member States have introduced a new concept of agroeconomic development - professional training that encourages people who deal with agrarian delicacy, primarily in rural areas, to enter new forms of agrarian business, to introduce modern technologies in production, environmental protection culture and other.

That's how economy of knowledge is created both in theory and in practice, and in terms of production, it is called a knowledge-based economy (Pejanović, 2013, p.620). 
The importance of education, i.e., the knowledge, is in the fact that when faced with the choice between different goals, it enables us to be fully aware of our choice. As Robins said: "In order to be rational, we need to know what we prefer, we need to be aware of the consequence of alternative choices and the implications of the different goals for which we determine ourselves to."

Education which is in the function of work or occupation is the dominant need of the agrarian. For this reason, we wanted to gain insight into the educational needs for vocational education and training, and how much the content of the work in the agrarian defines the educational needs. This due to a fact that Serbia has not adequately adapted the strategy and goals of the creative re-transition of the agrarian sector through the application of acquired and new competent knowledge, and above all, by expressing the interest in vocational education and training. Nobel Prize winner Samiel Son states: "The choice of your cheerful profession is the most important economic decision that you will make."

The search for the resolution of contradictions in agriculture opens the space for expressing creativity and strengthening development strengths through various fields of education, learning and by acquiring skills, thereby affirming the practice of the modern formula of the agrarian development. Use of knowledge enables the liberation of economic laws, strengthening of productive and market rationality and optimal activation of development factors of the agrarian sector. Raising awareness, training and qualifications of employees represent the key factors in market competition. (Radovic Markovic et al., 2012, p.27). This will, on the one hand, enable the selection and dominance of the best, both the most competitive and the most competent, and on the other hand it will lead to higher productivity and efficiency of human labor, the improvement of production forces by opening the system towards the development forces of the society.

For this step, the fundamental application of new developmental philosophies and active creative potential is required, and without education, the space for their creativity, development and their applicative ability for changes in types of production, in technology, property relations, organization of work and management can not be opened.

Knowledge, production and innovation are three complementary phenomena that interact with each other and represent the most important sources of change and the basis of the construction of a modern agrarian system based on knowledge. Modern development trends in the market economy show that science and education are at the very top of the priorities of global and national strategies and policies for socio-economic and technological development and progress.

Combined human and social capital make up intellectual capital, which by applying knowledge, skills and overall behavior creates and adequately uses all other resources. (Pejanovic, 2013, p. 503)

This implies creative and synergistic use of resources, and above all competent knowledge applicable in different areas: transferable skills and knowledge, new vision of 
multidisciplinarity, as well as transdisciplinary competencies expressed through interest in professional education and training.

So, "The road to a developed society requires good quality education for all", and the economy of knowledge is the main tool for a new model of economic and social growth and development.

Education for the 21 st century is not just one of many instruments of development; it is also one of its essential objectives and one of its components. (Delors, 1996, p. 69)

Compelling arguments are evident in the economic literature regarding the role of education in agriculture. In all the studies we analyzed, the average increase in agrarian production for 4 years of education in traditional conditions was $1.3 \%$ compared to $9.5 \%$ increase in modernized business conditions of agrarian organizations.

Most likely that even if we include more literature extracts covering the share of education, it would be insufficient. But even such a modestly developed insight into the literature shows and proves the seriousness of the educational role in agricultural development through values, abilities, knowledge, habits, competences and employees skills.

Jacques Delors said: "The concept of lifelong learning is the key to opening the door of the 21st century" (Delors, 1996, p. 99).

\section{Empirical research}

In line with the theoretical research, our empirical research has been focused on determining the interdependence of education and the work content of the employees in the agrarian sector.

By inspecting the diversity of needs, especially on the "scale" of educational impulses, conditions are created for designing education strategies in which all categories of employees in agrarian sector may pursue and use their chance and accelerate the innovation of their work activities to stimulate and enrich their activity with new quality methods and techniques and significantly enhance the capacity and variety of creativity.

Through the empirical research, we tried to determine the employees' attitudes on the utilization of acquired knowledge, during their education within their work organization, on the contribution of education and knowledge to the economic performance of the agrarian unit, how much education serves the function of technical and technological development, as well as the motives for the employees to engage in education, etc.

The survey was carried out on a sample of 470 employees from different working communities of agricultural organizations and different levels of education. 
Table 1. Sample structure

\begin{tabular}{|c|c|c|c|}
\hline $\begin{array}{c}\text { Marking / } \\
\text { Designation }\end{array}$ & Sample & $\mathbf{N}$ & $\%$ \\
\hline \multirow{3}{*}{ Sex } & Male & 382 & 81,3 \\
\hline & Female & 88 & 18,7 \\
\hline & Total & 470 & 100,0 \\
\hline \multirow{7}{*}{ School completed } & Primary & 103 & 21,9 \\
\hline & Secondary & 239 & 50,8 \\
\hline & Higher education & 34 & 7,2 \\
\hline & $\begin{array}{l}\text { College / } \\
\text { University }\end{array}$ & 69 & 14,7 \\
\hline & M.A. & 17 & 3,6 \\
\hline & $P h D$ & 8 & 1,7 \\
\hline & Total & 470 & 100,0 \\
\hline \multirow{6}{*}{ Work content } & $\begin{array}{l}\text { Direct agrarian } \\
\text { operators }\end{array}$ & 214 & 45,5 \\
\hline & $\begin{array}{l}\text { Managers and } \\
\text { experts }\end{array}$ & 46 & 9,8 \\
\hline & Direct managers & 82 & 17,5 \\
\hline & Scientists & 47 & 10,2 \\
\hline & Administration & 81 & 17,2 \\
\hline & Total & 470 & 100,0 \\
\hline
\end{tabular}

Respondents were surveyed individually and in smaller groups mainly in their workplace. The research was conducted during 2016 and 2017.

\section{Results of research and discussion}

\section{Employee attitudes about the usability of the acquired knowledge during the education at the work they perform (Chart 1)}

Utilization of knowledge acquired during schooling - Education is an important factor of productivity and economic performance. Our respondents believe that they use the acquired knowledge from the school at work (Chart 1): enough 8.2\%, slightly 33.7\%, and not at least $58.1 \%$. These results are troubling, but expected at the same time, given the educational structure. 
Figure 1. Employee attitudes on usage of knowledge acquired at work they perform

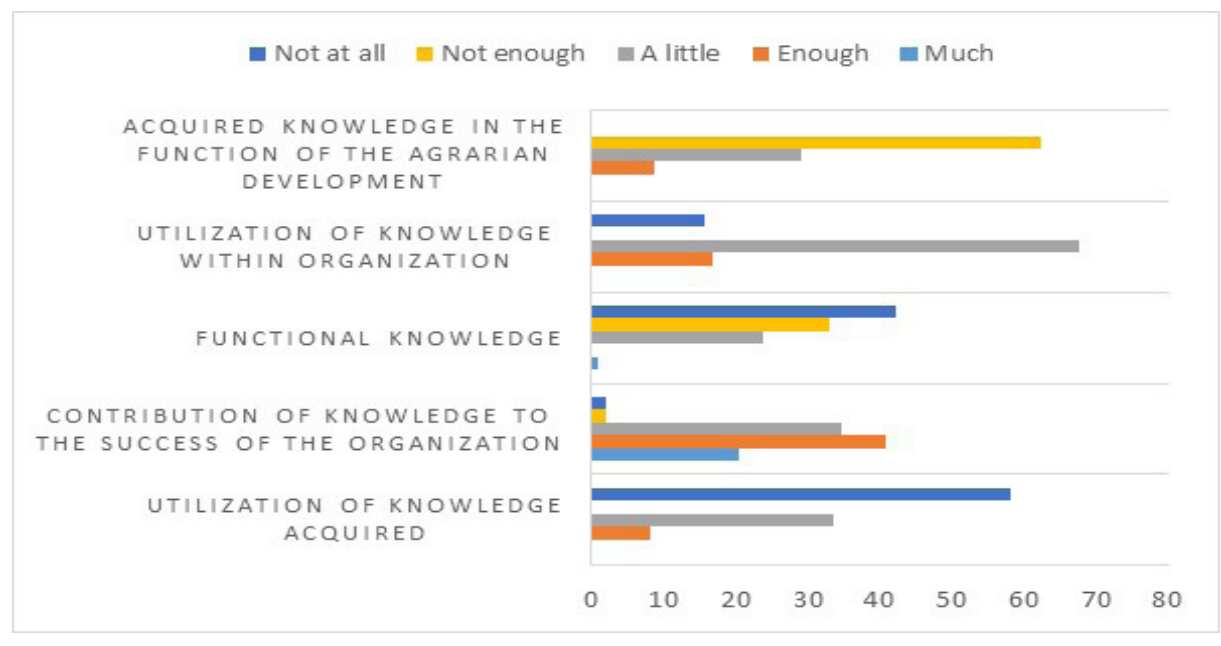

Source: Authors' calculations

Attitudes of employees regarding the contribution of knowledge and education to the economic performance of their organization: (Chart 1) - The results show that employees appreciate the contribution of knowledge and education to the economic performance of the organization: $20.5 \%$ sufficient, $40.8 \%$ enough, $34.7 \%$ not enough and $2 \%$ not at all. (Chart 1) The results obtained are not surprising, but it is difficult to say whether it is a consequence of the contents of the work or level of education of the respondents or some other factors.

Evaluation of the functionality of knowledge gained during schooling - The problem of the functionality of knowledge acquired in education is a serious problem, since it is certain that neither the economy nor the school are satisfied with the degree of usability of knowledge acquired through education. Direct agriculturists quite negatively evaluate the usability of knowledge at work acquired in school (Chart 1): 1\% - sufficient, $23.7 \%$ - enough, 33\% not enough and $42.3 \%$ no at all, which is in correlation with their level of education and content of their work. However, there are important differences depending on the content of the work of the employees in the agrarian sector, or between the professional categories. The most positive attitude towards the functionality of the knowledge gained by education was made by the researchers $71.4 \%$, while in a relatively modest percentage such direct opinions and technical and engineering personnel account for $9.9 \%$, senior executives and experts $15.2 \%$ and administrative staff $5.1 \%$ etc. And if different interpretations of these results are possible, it seems that more and more criticism of this problem is expressed by professional groups that need practical knowledge which is not really sufficiently provided by our education by achieving the connection between theory and practice.

The gap between the "world of work" in agrarian and "world of education" is huge. A high degree of criticism of the current concept of education has been demonstrated, i.e. it is believed that the educational institutions are not sufficiently in the function of work. 
Readiness of the organization to use the knowledge and skills of employees (Graph 1) - Indicator of the organization's readiness to encourage education and acquisition of knowledge and its endeavor to fully utilize the knowledge and ability of employees is a significant motivational factor in education and the contribution of knowledge and education to the economic success of growth and development of the organization. Based on the established statistical indicators, we can conclude that the subjective assessment of the respondents about the readiness of the organization to use the knowledge and abilities of the employees significantly depends on the employees' work content. Almost two thirds of the results are grouped around the middle half of the variable - sufficient $(67.7 \%)$, and according to the negative gender variable - insufficient $(15.6 \%)$, and enough $16.7 \%$ of the respondents. In terms of the readiness of the organization to use the knowledge and skills of the employees the most critical are the direct executors in the agrarian sector, $28.9 \%$, the direct managers and the engineering-technical staff (25.8\%). As a rationale for this result, this result may serve with related research that in an agrarian organization, knowledge and education is less valued than in other organizations.

The assessment of the respondents how much educational knowledge is in the function of technical and technological development of the agrarian - the remark that the education system does not adequately respond to the requirements of scientific and technical changes are not without basis, because in our research on the question of how much school knowledge in the function of technical and technological changes, a great number of respondents estimate that knowledge is $62.4 \%$ insufficient, not enough $29 \%$, and only $8.6 \%$ are sufficient (Chart 1). The most critical were the direct executors in the agrarian sector, who have the least knowledge in the field, which has certainly affected their assessments, while researchers, technical intelligence and senior executives and experts consider the educational knowledge to be in the function of technical and technological changes.

The fact that this result is not accidental is confirmed by the findings of other authors as well as in our research on the assessment of respondents that they are not familiar with technical and technological changes where almost $2 / 3$ respondents answered insufficient 59.4\%, not enough $32.3 \%$ and enough $8.3 \%$. The results indicate that the employees did not acquire enough knowledge for technical and technological changes, that is, after finishing school they did not supplement and refresh their knowledge in the profession, especially knowledge in the function of technical and technological development. Researchers are the only professional category that is fully familiar with technical and technological changes.

\section{Motives for inclusion in education}

The largest number of examinations shows that the most important place on the list of motives for the education of agricultural workers is "higher personal income" and "better workplace", also shown by our research, which follows this logic. 
Figure 2. Employee attitudes on motivation for inclusion into education

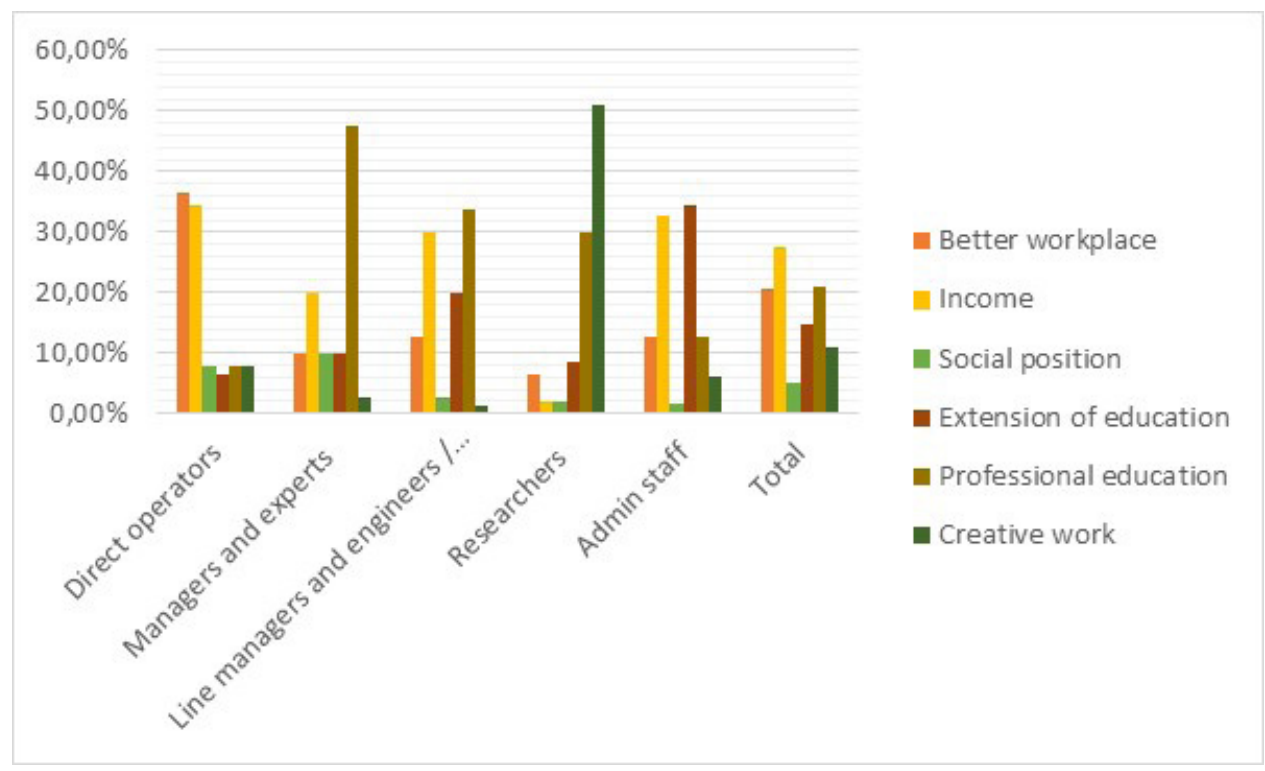

Source: Authors' calculations

The results obtained are in line with previous research and confirm that the increase in personal earnings is the most frequent motivator for education and training of agrarian employees $(26.8 \%)$.

The fact that the material gain is a priority motivator for the training of agricultural workers is confirmed by a significant number of employees who perceive the education as a way of getting a better job (20.1\%).

This phenomenon of education and learning motives may be explained by an instrumental theory of motivation which basically involves participation in educational activities as a link to the ability to achieve the most important personal goals - higher personal earnings and a better work position.

Desire for professional development in the field is ranked in the third place when it comes to motives for education with employees in the agrarian sector $(20.5 \%)$.

This type of motivation often remains outside the educational organizations, since the agrarian employees rely on individual work to expand their professional knowledge to read books, professional journals, engage into personal contact with scientists and people who can help them.

The wish to expand education with agrarian employees as a motive for learning shows that employees are interested in expanding their knowledge and culture (14.8\%) represents a very positive result. On the other hand, this also shows the desire of employees to get involved in all forms of education. 
The possibility of creative work represents a significant motive (10.8\%). The result is not surprising, inter alia, due to the structure of the sample in which researchers are significantly present and also because of the structure of labor within the agrarian sector.

For the employees in the examined organizations social position was, quite expectedly, not particularly important for learning.

It was natural to assume that the content of the agrarian work is a variable, which is significantly related to the choice of motives for education and training. This assumption is fully confirmed by the hypothesis set: The content of the work in the agrarian sector significantly influences the attitude of employees towards education and motives for inclusion in education and professional development.

Similarly, we can conclude, with high statistical probability, that in terms of content, respondents differ in the preferences of motives for inclusion in education and training.

The results of the survey showed that the most important motive for direct executors in agrarian $(36.36 \%)$ was a better work position, and a large number of respondents in this category see better personal income (34.3\%) as a motive for education and professional development.

With direct executives and engineering staff, the most important motive for inclusion in education is the professional training with $33.6 \%$, followed by personal income with $30.0 \%$, while administrative staff rather opts to engage in expanding their education with $34.4 \%$ to the personal earnings with $32.8 \%$

The possibility of creative work as a motive for learning is ranked first with researchers (51.1\%). Researchers show a high percentage of desire for professional development (29.8\%).

\section{Selection of Educational Area}

We have assumed that the position in the occupation is a differential variable serves as the basis on which the examination of the category of employees in the agrarian sector varies considerably in the selection of the educational area, as evidenced by the results obtained in this research.

Responses to the questionnaire in this area (Chart 3) were given by 255 employees $(54.3 \%)$, so $45.7 \%$ of employees can be considered as absolutely not interested in any form of education and training. It can be concluded that the employees who were interviewed showed a satisfactory level of interest in meeting educational needs in different areas of education and training.

The largest number of employees is interested in vocational education $45.1 \%$, followed by vocational training with $24.7 \%, 16.4 \%$ decided to retrain, and pursue education from the socio-economic field $10.2 \%$ and $8.6 \%$ of employees are interested in specializations.

Therefore, vocational education represents the dominant wish of the largest number of employees, especially for the fact that a professional training intended for a work post through the retraining program and specialization are in the function of vocational education. 
There is a significant difference among the examined groups when it comes to the choice of the field of education. Thus $64.3 \%$ of researchers, direct managers and technical staff choose vocational education with $51.8 \%$, followed by administrative workers with 51.6\% and senior managers and experts with 50\%. Almost identically administrative staff (32.3) and direct managers and technical staff (32.1\%) were identified for vocational training. As the third educational area, the retraining has been singled out, where the most interested parties are among the direct executors in the agrarian sector (36.4).

Figure 3. Employee attitudes about the choice of educational area to choose

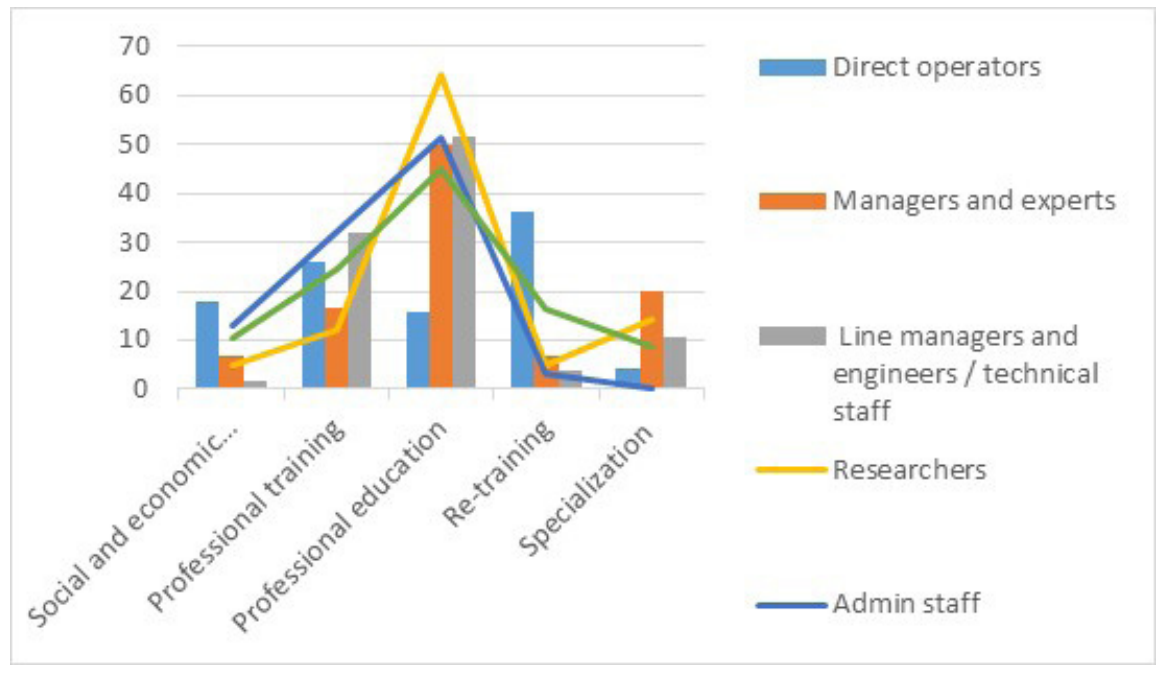

Source: Authors' calculations

The specialization program was attended by senior managers and associates in the largest percentage of $20 \%$, while no administrative staff attended this field of study, and other professional categories did not have much participation in specialization programs.

\section{Activities employees devote themselves after working hours and importance of education in these activities}

By combining the content of work in the agrarian with the activities of employees after working hours, it has been determined that the examination of the group of employees varies considerably in the selection of activities. The most frequent activity after working hours go to household and family obligations (47.45\%): for direct executives in agrarian (52.3\%), as well as with administrative staff $(62.9 \%)$, which is expected for administrative staff, since the largest number of respondents are women. 
Figure 4. Employee activities after working hours

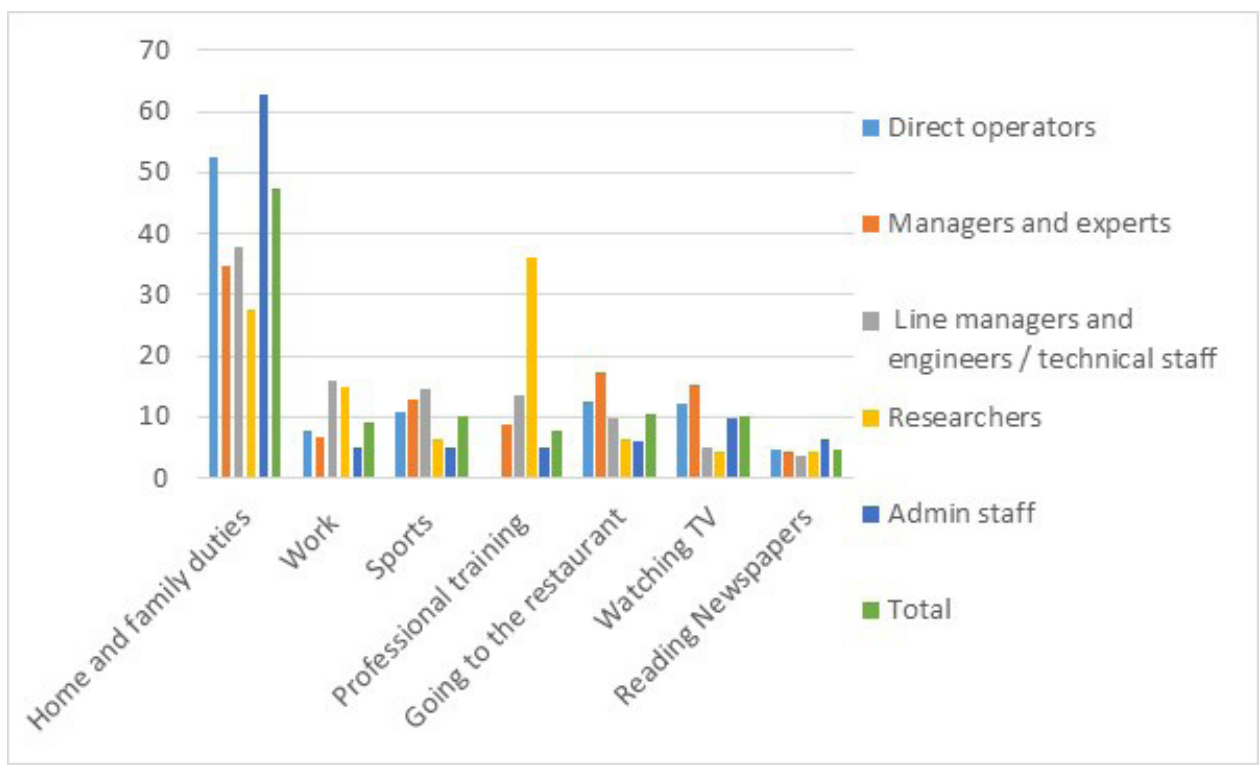

Source: Authors' calculations

It is interesting that direct agriculturists are not interested in education as an activity after working hours. This activity was rarely picked by administrative staff (4.9\%), while senior managers and experts $(8.7 \%)$ and direct managers and engineeringtechnical staff $(13.4 \%)$ chose it in a slightly higher number. In case of research staff within the organization, learning and education occupy the most important position in post-business activities. Thus, $36.6 \%$ of research staff chose education and training as a post-job activity, and followed by activities related to domestic and family obligations $(27.7 \%)$ and job-related activities $(14.9 \%)$. It is obvious that learning and education among researchers has a dominant place in terms of after working hours activities, and that direct executors in the agrarian sector do not find themselves in these activities.

\section{Analysis of results and conclusions}

After analyzing the results of the research, we determined that the content of the work in agrarian, through groups of occupations and jobs, significantly influenced the attitude of the employees towards education. This impact is slightly reduced when age and school are taken into account, where older respondents generally have a negative attitude towards education from younger ones, while employees with higher education take a positive view of the contribution of education to the content of work in relation to employees with lower levels of education. Researchers have the most positive attitude towards education, and the most negative direct executors, which is in line with our assumptions and expectations, as well as the results of related research. 
The research has determined the order of motives for education of employees in agrarian sector: increase of personal income; getting a better job; the desire to improve within the profession and the desire to expand knowledge.

The assumption has been confirmed that the content of the work appears as a variable significantly related to the choice of motivation for inclusion in educational activities. Direct agriculturists are dominantly occupied with motifs of utilitarian character.

The results of the research confirm to a great extent the results of our and foreign authors in relation to the interest of agricultural workers in certain types of education, and that the content of the work defines the variable of the preference of employees in the field of acquiring knowledge. At the same time, it would be desirable and necessary for the researchers of this the content of work as an incentive factor of education and learning is directly related to the wider environment, that is, socio-cultural environment, but also to the intellectual and psychological characteristics of the employees in the agrarian sector.

When determining the area and content of education, the practical requirements of the work and work situation of the employees must be taken into account. For example, it is expected that the primary interest of direct executors in agriculture is primary adult education, vocational training for workplace and retraining, while a small number of them are interested in programs with wider professional knowledge, which is mainly characteristic for other professional groups in the agrarian organization.

The conducted research, analysis and interpretation of the results of the research serve the function of perceiving, defining and understanding the direct contribution of education and its impact on the positive problems and development of the agrarian sector in the Republic of Serbia.

Agriculture needs something different from what we have today - expanding the space of science and education for new innovative programs with clearly controlled quality criteria. It is necessary to build awareness of interactive links between socio-economic development and education.

Large and far-reaching changes in the structure and content of work and work based on automation and high technologies, the intellectual content of rationalizing and innovative activities strongly affirm the need for continuous learning and education and an interest in the various dimensions of the professional and overall development of man and his civilization values.

The main challenge of the future period is the achievement of structural changes in agricultural development through the creative and synergistic use of resources, and above all the competitive knowledge.

Scientific study confirms that work and education, in agriculture, as an indispensable factor of social and personal development have an extremely important place and role in encouraging and satisfying different human needs. 


\section{Business and social skills - contemporary success formula}

Are we a pilot or a traveler in life, work and time?

The fact is that time does not wait for anyone and successful people distinguish from the unsuccessful by the way they manage their time. To be successful does not mean that we need to work more but smarter.

Life and time often put us on test and face us with our own unrest, fears, successes and failures. How to overpopwer yourself, where there is just one problem, and that is me. We can not choose whether we will spend time, but rather how we spend it. Every day is a fresh account with 86,400 seconds or 1440 minutes.

Behavior in time management may be characterized as a combination of time estimation, goal setting, planning, and tracking activities. (Hafner, Stock, 210, p. 430) Time management is the way of life, a set of activities, procedures and resources in order to efficiently and effectively uses our time, both in business and in private life.

We will never have time for everything, and what may be done at any time is never done.

The key to success is dealing with solutions rather than problems through the stimulation of thought processes. The goal is to answer each question with another question, which literally makes you come up with the answer yourself. How - by taking an insight into your own way of thinking. This requires knowledge and skills, the existence of a positive goal and good intention; we need to know what we want. For someone, the reality is the cultivation of cucumbers, and for some other - aircraft production, the conquest of power, and so on.

Real goals are seen only by high rollers. Anything is possible; those who want to find a way will find it and those who don't, will find an excuse not to.

New time requires new knowledge and skills - application of new and creative techniques and coaching models that allow you to feel inspiring, to face both yourself and problems. One has to be brave in presenting himself in time and space in which we live and work.

The consequences of poor time management are poor communication, loss of creativity, search for good solutions, lack of determination and influence, conflicts, low probability of getting what is desired and a lot of stress.

This will be supported by the research on how managers manage their time: $54 \%$ work more than 10 hours a day, $71 \%$ regularly take their work home, $75 \%$ have dreams about work, 75\% say they can't sleep due to their worries about work, 57\% postpone their holiday or weekend. It is clear here that the managers are controlled by their duties, not vice versa. Managers direct their own energy against themselves.

Bad time management is one of the biggest causes of stress. 
People are increasingly disintegrated by their individual networks and their relationships become increasingly complex and unpredictable, essentialy due to egoism and subjectivity, they are burdened with themselves, the individual wellbeing becomes more important than the general wellbeing.

So, the time will not let down those who can use it well.

Good quality organization requires time, but disorganization requires much more time. The trick is not to do everything, but to do what is important. We will remind you of Maximen's law: "I never have time to do it right, but there is always time to do it again". Very important assumption is to know your limits.

Which one is the right way when each one one apparently looks like the other one?

Thomas Edison once said: "I have not failed. I've just found 10,000 ways that won't work."

Don't let others to manage your time, organize yourself: set goals, sort them according to priorities and develop the action strategy, avoid activities that waste your time, simply say NO!

The success formula largely depends on the stress management on daily basis, representing the limiting factor of success. Under the "stress" we usually refer to the "physical and psychological tension that an individual feels when faced with the temptations of extraordinary demands, pressures or opportunities whose outcome is considered uncertain and important." (Robbins, Coulter, 2005, p. 323)

There are more and more disoriented angry, helpless, and apathetic people with failed expectations that are under constant stress.

What does a wise and successful man do when he experiences a fall? He rises and moves further aware of the price that he had to pay to get some crucial knowledge. Therefore, it is necessary to search for the truth in the desire to defeat the need for self-deception. Victory or defeat, success or failure, represent a large pot of challenges and chances.

Is there a guaranty? No!

"Stress and depression are the most widespread diseases of today", as told by psychiatrists and psychologists. That is a tribute that man pays to the computerization and subjugation of his to the career. (Pajevic, 2006, p. 297)

In such a virtual reality in which we live, our perceptions are easily changed; everyone has their own vision, their perception of reality, their expectations and personal desires. We are surrounded by "lightweight solutions", and technology and parallel information have created a new front of deception.

Can we learn to manage the stress?

Everything in life can be learned, even the stress management.

Approach to "hot" issues requires calmness. 
We are part of the problem, but we are a very important part of the solution. If we can't solve a problem then it is no longer our problem. You have to decide what matters to you: to be right with your beliefs or to be successful and happy, because both do not go together.

Good business communication is one of the imperatives of successfully implemented of business ideas, as an inevitable process that should be constantly evolving. The right information at the right time is crucial for the quality of business decisions and decision making, increasing the speed of business processes and with the function to increase profits. (Karavidic, Radovic-Markovic, Cukanovic-Karavidic, 2013, p.229)

Essential importance of business communication is realized in the implementation of the goals of the agrarian organization; their development plan; organization of human and other resources in the most successful and efficient way; selection, development and evaluation of the organization members; guiding, motivating and creating a business climate and controlling overall organizational activities.

The expression of face and body language - non-verbal communication (50\% - 55\%) has the biggest influence on the interlocutor, then the way and tone of speech - interpretation (38\% - 40\%), while the content of spoken has the lowest influence (7\% - 10\%). (Bojanovic, 1998)

In doing so, one has to bear in mind what is characteristic for the message we send, what we want to challenge with the interlocutor, and how it will achieve its goal.

Modern methods of business communication have implications on work efficiency and economy, as well as on the establishment of a good quality business relationship, the relationship of trust and personal responsibility.

Table 2. Methods and professionalism in communication

\begin{tabular}{|l|l|}
\hline PROFESSIONAL COMMUNICATION & $\begin{array}{l}\text { NON-PROFESSIONAL } \\
\text { COMMUNICATION }\end{array}$ \\
\hline BODY LANGUAGE: posture, movements, seating, standing, walking \\
\hline Relaxed, calm, open & Stiff, cold, distant, tense \\
\hline MIMICS: forehead, eyes, eyebrows, mouth ... \\
\hline $\begin{array}{l}\text { Open, cheerful, eyebrows calm, mouth with a } \\
\text { light smile... }\end{array}$ & $\begin{array}{l}\text { Frowned forehead, frowned face, compressed } \\
\text { eyebrows, mouth... }\end{array}$ \\
\hline EYE CONTACT: watch your interlocutor \\
\hline $\begin{array}{l}\text { Looks at the interlocutor as he talks to him, } \\
\text { watches his movements, does not blink... }\end{array}$ & $\begin{array}{l}\text { Does not look at the interlocutor, avoids eye- } \\
\text { contact, goes through papers aimlessly, looks } \\
\text { down ... }\end{array}$ \\
\hline SPEECH: speed, rhythm, depth, voice, melody, laughter... \\
\hline $\begin{array}{l}\text { Speaks slowly and clearly, makes breaks, } \\
\text { does not make unnecessary digressions... }\end{array}$ & $\begin{array}{l}\text { Speaks cold and fast, nervously, makes no } \\
\text { breaks, supports conversation with different } \\
\text { gesture... }\end{array}$ \\
\hline \begin{tabular}{l} 
GESTICULATION: arms and legs (applauding, mild touching of shoulders, etc.) \\
\hline $\begin{array}{l}\text { Arms slightly lowered, calm, during } \\
\text { the conversation makes sure to keep the } \\
\text { interlocutor in an equal position. }\end{array}$
\end{tabular}$\quad \begin{array}{l}\text { Too much arm movement or keeping arms } \\
\text { crossed; seated with legs crossed, taps } \\
\text { nervously... }\end{array}$ \\
\hline
\end{tabular}




\section{Conclusion}

Through the theoretical and empirical research in this paper, we have confirmed the importance of education, knowledge and social skills on the institutional basis and the creative modernization of agrars that have, by changing the global economy, growing transitional contradictions and interest matrices, found itselves at a complex crossroads and in the numerous problems of its development.

Science and education represent the main drivers of economic development and its values, and the work (content of work and education) is the main pillar that connects many economic activities and represents the whole value of social development - the path and course of its development, the source of value. Because the world is going through a new technological revolution, social networks, applications and virtual currencies that change the global economy.

Education and learning may accelerate changes in the content of work and area of work, stimulate and accelerate the enrichment of work with new methods and techniques and greatly contribute to the improvement of one's creativity and lifestyle - the desire for success and satisfaction.

We are aware of the complexity of the problem examined, all difficulties in organizing education and the content of work and its elements as a success formula. Therefore, our theoretical and empirical research should be understood as an attempt to partially find out the essence of the interdependence of socio-economic development with the content of work and education in order to determine the positive indicators of these relations and to resolve the contradictions and doubts noted so far. In this we find a certain significance and value of our research work, which, hopefully, will start new research and discussions about this important problem.

It's never too late to change direction towards realistic and achievable goals with the motto: it must be better than this.

This may be the right time for that.

\section{Conflict of interests}

The authors declare no conflict of interest.

\section{References}

1. Aeon, B., Aguinis, H. (2017). It's about time: new perspectives and insights on time management, Academy of Management Perspectives, Vol. 31, No. 4, pp. 309, https://doi.org/10.5465/amp.2016.0166

2. Alan, Dž.R. (2008). Creative Intelligence - Discover innovative potential in yourself and others. Belgrade: Clio. [in Serbian: Alan, Dž.R. (2008), Kreativna inteligencija - Otkrite inovativni potencijal u sebi I drugima]

3. Andric, J. (2003). Management, marketing and information systems in the function of agricultural development. Zemun: Faculty of agriculture. [in Serbian: Andrić, J. (2003), Menadžment, marketing i informacioni sistemi u funkciji razvoja poljoprivrede] 
4. Bojovic, R. (1998). Psychology of interpersonal relations. Belgrade: Serbian Psychological Society. [in Serbian: Bojović, R. (1998), Psihologija medjuljudskih odnosa]

5. Delor, Ž. (1996). Education discovered treasury. Belgrade: Ministry of Education of the Republic of Serbia. [in Serbian: Delor, Ž. (1996), Obrazovanje otkrivena riznica]

6. Džudit, L.Dž. (2008). Inspirational manager - how to build relationships that bring results. Belgrade: IPS Media [in Serbian: Džudit, L.Dž. (2008), Inspirativni menadžer - kako izgraditi odnose koji donose rezultate]

7. Edvard, B. (2008). Course of thinking. Novi Sad: Asee [in Serbian: Edvard, B. (2008), Kurs razmišljanja]

8. Fransoa, P. (2008). For the philosophy of new development - development trends. Belgrade: European centre for peace and development [in Serbian: Fransoa, P. (2008), Za filozofiju novog razvoja - trendovi razvoja]

9. Hafner, A., Stock, A. (2010) Time Management Training and Perceived Control of Time at Work, The Journal of Psychology, 144(5)

10. Karavidic, S., Radovic-Markovic, M., Cukanovic-Karavidic, M. (2013). Entrepreneurship: Contemporary development trends. Belgrade: VSPEP Faculty of business economics and entrepreneurship [in Serbian: Karavidić, S., Radović-Marković, M., Čukanović-Karavidić, M. (2013), Preduzetništvo: savremene tendencije razvoja]

11. Masaki, Z. (2008). Kaizen - Kaizen -the key of Japanese business success. Belgrade: Mona \& Manjana [in Serbian: Masaki, Z. (2008), Kaizen - ključ japanskog poslovnog uspeha]

12. Pajević, D. (2006). Psychology of work. Beograd: Liber [in Serbian: Pajević, D. (2006). Psihologija rada]

13. Pejanovic, R. (2013). Experiments from agrarian and rural economies. Novi Sad: Faculty of agriculture [in Serbian: Pejanović, R. (2013), Ogledi iz agrara i ruralne ekonomije]

14. Pejanovic, R. (2005). Transition and agro-industry. Beograd: Business policy [in Serbian: Pejanović, R. (2005), Tranzicja i agroprivreda]

15. Radovic Markovic, M., Grozdanic, R. Kvrgic, G., Markovic, D., Vujicic, S. (2012), New educational strategies versus the traditional methods. International Review, No.1-2, pp. 27

16. Robbins S., Coulter M. (2005) Management, Beograd: Data Status, str. 323. [in Serbian: Robbins S., Coulter M. (2005), Menadžment]

17. Stevanovic, S. (2010) Agribusiness management in the RS in conditions of globalization and transition (doctoral thesis). Valjevo [in Serbian: Stevanović, S. (2010) Upravljanje agrobiznisom u RS u uslovima globalizacije i tranzicije] 